\title{
Academic Success Scale: Second-Order Confirmatory and Exploratory Factor Analysis
}

\author{
Şefika Şule ERÇETINN${ }^{1}$, Halime GÜNGÖR² ${ }^{2}$ Mehmet Ali HAMEDOĞLU³
}

\begin{tabular}{l} 
ARTICLE INFO \\
\hline Article History: \\
Received 11.12 .2019 \\
Received in revised form \\
26.04 .2020 \\
Accepted \\
Available online 01.07 .2020
\end{tabular}

\begin{abstract}
Background: One of the most important tasks of the education system is to follow the academic development of students by using measurement and evaluation methods and techniques, and to direct them to the areas where they will be successful and happy in line with their interests and abilities. Objectives: Aim of the study is to develop a measurement tool that determines factors affecting the academic success of students in the school environment in the process of preparation for higher education. Methods: The validity and reliability studies of the scale were conducted with the 348 participants in the first and with 168 participants in the second application. Results: As a result of exploratory and second order confirmatory factor analysis, the scale consisting of twenty six items and six factors was found to be theoretically and statistically appropriate. Conclusion: Since there are few tools that measure the factors affecting academic success in the literature review, it is thought that the scale will contribute to the field in literature and can meet this need.
\end{abstract}

CC IJERE. All rights reserved

Keywords:

Academic success, validity, reliability, scale, second order CFA

\section{INTRODUCTION}

The school is place where formal education processes are carried out, which prepare the students for life and in which the demands and expectations of the individuals in accordance with the living conditions in adulthood are shaped to a great extent. As students prepare for the exam in the process of transition to secondary education and higher education in Turkey; academic success is one of the most important factors in determining which schools students will attend in higher education and it is very important for students, teachers, and administrators who are the main actors in schools. Indeed, the situation in terms of future career expectations as required by the education system in Turkey is largely determinant of academic success. The most important factors that affect academic success are school administrators, teachers, students, characteristics of school and parents. Therefore, leadership is the most critical process at all educational levels and in all types of educational institutions (Erçetin and Bisaso, 2018). On the other hand, teachers are, in a sense, one of the most important factors that build and shape the future (Erçetin and Çevik, 2019).

One of the most important tasks of the education system is to follow the academic development of students by using measurement and evaluation methods and techniques, and to direct them to the areas where they will be successful and happy in line with their interests and abilities. Success in formal education in Turkey determined the extent of the students' achievement tests scores taken in exams. Parents suggest that their children must be academically good and should get high marks from exams and may even put pressure on them. At this point, academic success or school success becomes more important. From the social point of view, it is accepted that individuals with high academic achievement are more successful in the transition to higher education exam and they are placed in the departments with higher scores and are included in the occupational groups with the potential of qualified labor force.

\footnotetext{
${ }^{1}$ Author: Orcid ID: https://orcid.org/0000-0002-7686-4863, Hacettepe University, Ankara, Turkey, sefikasule@gmail.com

${ }^{2}$ Author: Orcid ID: https://orcid.org/0000-0002-3283-1250, Hacettepe University, Ankara, Turkey, gungor.halime@gmail.com

${ }^{3}$ Author: Orcid ID: https://orcid.org/ 0000-0003-2833-2931, Sakarya University, Sakarya, Turkey mhamed@sakarya.edu.tr
} 
One of the most important aims of educational institutions is to educate academically successful individuals. Today, students' success, which is a necessity of the age rather than the aim of education, changes the traditional perspectives of learning and persistence of knowledge and gives opportunities for new models and insights (Eker and Coşkun, 2012). Community empowerment is a process that succeeds in the education system to educate individuals in accordance with the needs and expectations of the society. Social needs and expectations evolve to the appropriate age. There is no doubt that our universe has evolved in terms of lifestyles and perceptions of education (Erçetin and Açıkalın 2018). In the developing and evolving world order, educational institutions, administrators, teachers, students, the qualifications of the schools and the parents of the students as the components of the education system have been experiencing a changing process. In this sense; academic success can be defined as individuals' achievement of their goals by showing behaviors in line with the determined performance indicators and in line with the objectives of the educational programs. Therefore, the adaptation and evolution of educational programs is important.

When studies related to academic success are examined, it can be said that different measurement tools, methods and techniques are used by the researchers to measure academic success. For example; a qualitative research carried out by Erçetin and Arifoğlu (2016) with the aim of examining and evaluating Turkey's education policies implemented over the period of 2000-2015 from a broad perspective within the scope of "Education for All" goals. According to the results obtained from the research; the schooling rates of this age population increase with the increase of compulsory education to 12 years; girls benefit from this education at the same rate as boys; one of the important problems that continue in secondary education is that the mismatch between the knowledge and skills that young and adults will need in life and the skills that they learn in school environment; continuing problems about balance balance between general secondary and vocational secondary education persist.

Another study was conducted by Bakioğlu and Salduz (2014) in order to examine views of teachers in secondary education on the accountability system about the academic success of students. In the research, the Questionnaire of the Teachers' Accountability Evaluations about the Academic Success of the Student, which was developed by the researchers, was used as a data collection tool. According to the results obtained from the research; it was found that teachers think that teachers should be accountable after students about academic success.

In the study conducted by Özer and Demir (2008) in order to determine the factors affecting the success of the students who are prepared for the Student Selection Examination (ÖSS) and to determine the direction and magnitude of the effects of these students on the success of the students; the data were estimated by using the least squares (SEK) method using the cross-sectional data obtained from the questionnaires applied to the senior students of Oltu Anatolian High School in the 2005-2006 academic year. According to the results of the research, it was determined that the classroom and motivation trips had a significant effect on students' numerical and equal weight scores.

In this context, the aim of study is to develop a measurement tool that determines factors affecting the academic success of students in the school environment in the process of preparation for higher education. In this study, the academic success of the students has been dealt with only in the context of preparation for higher education.

\section{Preparation Process Of The Scale}

Academic Success Scale was planned to be prepared in the three different forms for students, teachers and administrators. In this respect, the steps of the preparation process of the scales are explained below. The preparation steps of the Academic Success Scale are as follows.

1. In the preparation process, firstly the literature was searched, the existing studies on the factors affecting academic success were examined and the factors related to the school which were thought to affect academic 
success were listed in the literature review. In this respect, 34 items were prepared about the school which is thought to affect academic success.

2. After the literature review, the factors affecting academic success were dimensioned as school administrators and management style, parents, teachers, school qualifications and students. A pool of 76 items was formed as 11 for school administrators and management, 8 for parents, 15 for teachers, 27 for school qualifications, and 15 for students.

3. The items were discussed and evaluated; noticed that the school qualifications dimension contains different sub-dimensions within and decided to divide it into 3 sub-dimensions as curriculum, education and training environment and physical qualifications of school. Then, we re-worked on the 76-itemed pool.

4. Then, the scale is consisted of 50 items which are 7 items related to school administrators and management style, 7 items related to parents, 9 items related to teachers, 20 items related to the school qualifications which are 7 of curriculum, 7 of education and training environment, 6 of physical qualifications of school and 7 items related to students.

5. Then we received expert opinion from psychological counselors, managers and academicians on the 50item version of the scale. In the direction of expert opinions, the scale was reworked and a scale form consisting of 35 items, 5 items in all dimensions, was prepared.

6. After the scale was categorized into 5 dimensions as school qualifications dimension consist of curriculum, education and training environment and physical qualifications of school as sub-dimensions, school administrators and management style, teacher, parent, student dimension, a separate form was prepared for the three groups of Student Form, Teacher Form and Administrator Form of Academic Success Scale. In this context, the structural design of the scale is given in Table 1. 
Table 1.

Academic Success Scale Structural Design

\begin{tabular}{|c|c|c|c|}
\hline Categories & Student Form & Teacher Form & Administrators Form \\
\hline \multirow[t]{5}{*}{ Administrator } & My parents' participation in the school activities & Organizing activities for parents at school & Organizing activities for parents at school \\
\hline & $\begin{array}{l}\text { School management organizes reinforcement } \\
\text { courses to improve our course success }\end{array}$ & $\begin{array}{ccc}\text { Organizing reinforcement } & \text { courses } & \text { to } \\
\text { improve students' course success } & & \end{array}$ & $\begin{array}{ccc}\text { Organizing reinforcement } & \text { courses } & \text { to } \\
\text { improve students' course success } & & \end{array}$ \\
\hline & $\begin{array}{l}\text { Strict rules of conduct that we must obey at } \\
\text { school }\end{array}$ & $\begin{array}{l}\text { Application of discipline rules at school } \\
\text { without compromise }\end{array}$ & $\begin{array}{l}\text { Application of discipline rules at school } \\
\text { without compromise }\end{array}$ \\
\hline & $\begin{array}{l}\text { Rewarding the successful students by the school } \\
\text { administration }\end{array}$ & $\begin{array}{l}\text { Giving awards to students who are } \\
\text { successful by the school management in } \\
\text { ceremonies and / or meetings }\end{array}$ & $\begin{array}{l}\text { Awarding successful students in ceremonies } \\
\text { and / or meetings }\end{array}$ \\
\hline & $\begin{array}{l}\text { School management to support our needs when } \\
\text { necessary (food, service, materials etc.) }\end{array}$ & $\begin{array}{l}\text { Providing support to the students in need } \\
\text { (such as food, service, materials) by the school } \\
\text { administration }\end{array}$ & $\begin{array}{l}\text { Providing support to students in need (food, } \\
\text { service, materials etc.) }\end{array}$ \\
\hline \multirow[t]{5}{*}{ Parent } & $\begin{array}{l}\text { My parents come to school often to meet with } \\
\text { y teachers }\end{array}$ & $\begin{array}{l}\text { Parents come to school often to meet with } \\
\text { us }\end{array}$ & $\begin{array}{l}\text { Parents come to school when called by the } \\
\text { school administration }\end{array}$ \\
\hline & My parents meet my school equipment needs & $\begin{array}{l}\text { Parents meet the child's school equipment } \\
\text { needs }\end{array}$ & $\begin{array}{l}\text { Parents meet the child's school equipment } \\
\text { needs }\end{array}$ \\
\hline & $\begin{array}{l}\text { My parents support me to attend reinforcement } \\
\text { courses at school when I need them }\end{array}$ & $\begin{array}{l}\text { Parents support the child's participation in } \\
\text { reinforcement courses at school }\end{array}$ & $\begin{array}{l}\text { Parents support the child's participation in } \\
\text { reinforcement courses at school }\end{array}$ \\
\hline & $\begin{array}{l}\text { My parents motivate me to be successful with } \\
\text { various awards }\end{array}$ & $\begin{array}{l}\text { Parents take into account the warnings made } \\
\text { by us to make the child successful }\end{array}$ & $\begin{array}{l}\text { Parents take into account the warnings made } \\
\text { by the school administration for the child to } \\
\text { succeed }\end{array}$ \\
\hline & $\begin{array}{l}\text { Punishment by my parents of any misconduct at } \\
\text { school }\end{array}$ & $\begin{array}{r}\text { Parent's cc } \\
\text { student's inapprc }\end{array}$ & $\begin{array}{l}\text { Parent's cooperation with us to correct the } \\
\text { student's inappropriate behavior at school }\end{array}$ \\
\hline \multirow[t]{5}{*}{ Teacher } & $\begin{array}{l}\text { My teacher takes care of me when I have a } \\
\text { problem }\end{array}$ & $\begin{array}{l}\text { Dealing with the problems of my students } \\
\text { one by one }\end{array}$ & $\begin{array}{l}\text { Teachers one by one involvement in } \\
\text { students' problems }\end{array}$ \\
\hline & $\begin{array}{l}\text { When there is something I don't understand, my } \\
\text { teacher explains again }\end{array}$ & $\begin{array}{l}\text { Explain again when there is something my } \\
\text { students don't understand }\end{array}$ & $\begin{array}{l}\text { Teacher re-explain when there is a subject } \\
\text { that the student does not understand }\end{array}$ \\
\hline & $\begin{array}{l}\text { My teacher's use of technological tools to explain } \\
\text { the course }\end{array}$ & $\begin{array}{l}\text { Taking advantage of technological tools to } \\
\text { explain my lesson }\end{array}$ & $\begin{array}{l}\text { Teachers use of technological tools to } \\
\text { explain the course }\end{array}$ \\
\hline & My teacher makes the lesson enjoyable for us & $\begin{array}{r}\text { To make the lesson enjoyable for my } \\
\text { students }\end{array}$ & $\begin{array}{l}\text { Teachers make the lesson enjoyable for the } \\
\text { student to explain }\end{array}$ \\
\hline & $\begin{array}{l}\text { My teacher appreciates me in front of my friends } \\
\text { when I succeed }\end{array}$ & $\begin{array}{l}\text { Appreciating my successful students in front } \\
\text { of their friends }\end{array}$ & $\begin{array}{l}\text { Teachers appreciate successful students in } \\
\text { front of their friends }\end{array}$ \\
\hline \multirow[t]{2}{*}{$\begin{array}{l}\text { Educational } \\
\text { Curriculum }\end{array}$} & $\begin{array}{l}\text { In the daily curriculum, the succession of the } \\
\text { courses that I had difficulty such as mathematics and } \\
\text { physics }\end{array}$ & $\begin{array}{l}\text { In the daily lesson schedule, the succession } \\
\text { of the courses that my students have difficulty } \\
\text { such as mathematics and physics }\end{array}$ & $\begin{array}{l}\text { In the daily lesson schedule, the succession } \\
\text { of the courses that my students have difficulty } \\
\text { such as mathematics and physics }\end{array}$ \\
\hline & Taking two exams on the same day & Taking two exams on the same day & Taking two exams on the same day \\
\hline
\end{tabular}




\begin{tabular}{|c|c|c|c|}
\hline & $\begin{array}{l}\text { The content of the courses is at a level that we } \\
\text { can understand }\end{array}$ & $\begin{array}{l}\text { The content of my courses is at a level that } \\
\text { the student can understand }\end{array}$ & $\begin{array}{l}\text { The content of the courses is at a level that } \\
\text { the student can understand }\end{array}$ \\
\hline & $\begin{array}{l}\text { I can get support from the guidance service when } \\
\text { I need it }\end{array}$ & $\begin{array}{l}\text { My students can get support from the } \\
\text { guidance service when they need it }\end{array}$ & $\begin{array}{l}\text { Students can get support from the guidance } \\
\text { service when they need it. }\end{array}$ \\
\hline & Lack of empty course & The lack of teachers missing & The lack of teachers missing \\
\hline \multirow{5}{*}{$\begin{array}{l}\text { Education and } \\
\text { Training } \\
\text { Environment }\end{array}$} & Focusing on club activities at school & Focusing on club activities at school & Focusing on club activities at school \\
\hline & Crowded classes & Crowded classes & Crowded classes \\
\hline & $\begin{array}{l}\text { There are no cafes around our school to prevent } \\
\text { me from attending classes }\end{array}$ & $\begin{array}{l}\text { Lack of cafes around the school to prevent } \\
\text { my students from entering the class }\end{array}$ & $\begin{array}{l}\text { Lack of cafes around the school to prevent } \\
\text { students from entering the class }\end{array}$ \\
\hline & A wide range of resources in the school library & $\begin{array}{l}\text { A wide range of resources in the school } \\
\text { library }\end{array}$ & $\begin{array}{l}\text { A wide range of resources in the school } \\
\text { library }\end{array}$ \\
\hline & $\begin{array}{l}\text { We have computers in our school that we can use } \\
\text { to research on the Internet }\end{array}$ & $\begin{array}{l}\text { Having computers at school where my } \\
\text { students can use the Internet to conduct research }\end{array}$ & $\begin{array}{l}\text { Having computers at school where students } \\
\text { can use the Internet to conduct research }\end{array}$ \\
\hline \multirow{5}{*}{$\begin{array}{l}\text { Physical } \\
\text { Qualifications of } \\
\text { School }\end{array}$} & Sufficient course materials in our class & Sufficient course materials in our class & Sufficient course materials in our class \\
\hline & Lack of heating problem in our school & Lack of heating problem in our school & Lack of heating problem in our school \\
\hline & Our school is clean. & Our school is clean. & Our school is clean. \\
\hline & Classrooms are airy & Classrooms are airy & Classrooms are airy \\
\hline & $\begin{array}{l}\text { There is no sound during the course to prevent } \\
\text { the flow of the course from outside }\end{array}$ & $\begin{array}{l}\text { There is no sound during the course to } \\
\text { prevent the flow of the course from outside }\end{array}$ & $\begin{array}{l}\text { There is no sound during the course to } \\
\text { prevent the flow of the course from outside }\end{array}$ \\
\hline \multirow[t]{5}{*}{ Student } & Attending lesson effectively & Active participation of the student & Active participation of the student \\
\hline & Doing my homework regularly & Students do their homework regularly & Students do their homework regularly \\
\hline & Repeating daily topics & Regular daily repetition of the student & Regular daily repetition of the student \\
\hline & To know the methods of study & To know the methods of study & To know the methods of study \\
\hline & To prepare in advance for exams & To prepare in advance for exams & To prepare in advance for exams \\
\hline
\end{tabular}


7. Student, teacher and administrator forms were consisted that items in parallel with the content. Scale forms were finalized by taking the opinions of experts from the field of statistics and education management.

Before the application phase, personal information form was prepared at the last stage of the Academic Success Scale according to expert opinions and prepared for application as 3 forms, each consisting of 35 items for students, teachers and administrators.

In the Student Form, in the context of personal information, variables such as self-step, right-dead, togetherseparation status about parents, education status of the parents, gender, repetition status, and absenteeism status were taken into consideration. In the Principal Form, the variables of gender, educational background, experience of management, duration of work in the school worked in the context of personal information were taken into consideration. In the Teacher Form, variables such as gender, age, educational background, branch, seniority and duration of work at the school were taken into consideration. In order to ensure internal consistency, open-ended questions were asked at the end of the scale, "Can you write other factors that you believe affect the academic success of students at school? and What are your suggestions about what can be done at school to increase the academic success of the students?"

As a result of the first application, the scale was revised and reapplied. The personal information form of the scale, which was reduced to a single form in line with expert opinions, was taken into account the variables of duty (student/teacher/administrator) and gender in the school.

\section{METHOD}

\section{Sample}

The population of study is 211 official high school education institutions in Bursa . Based on the e-okul management information system, the base points of the 2014-2015 academic year were taken from the junior high school students of the 12th grade in the 2018-2019 academic year and the scores were ranked from small to large. In order to ensure internal consistency in the scale, both the most successful and the most unsuccessful schools were selected as samples. Öztimurlar Vocational and Technical Anatolian High School and Bursa Erkek High School which are among the lowest and highest schools were taken as the sample . The application was made by the researchers after obtaining the necessary permissions. The sample consisted of voluntary participation.

Table 2.

Characteristics of School Sample of the First and Second Application

\begin{tabular}{lccccccccc}
\hline Application School & \multicolumn{3}{l}{ Student } & \multicolumn{3}{c}{ Administrator } & \multicolumn{3}{c}{ Teacher } \\
& $N$ & $n_{1}$ & $n_{2}$ & $N$ & $n_{1}$ & $n_{2}$ & $N$ & $n_{1}$ & $n_{2}$ \\
& 662 & 130 & 51 & 5 & 4 & 3 & 72 & 60 & 8 \\
Öztimurlar VTAHL & 769 & 98 & 67 & 5 & 4 & 3 & 64 & 52 & 36 \\
Erkek High School & 1431 & 228 & 118 & 10 & 8 & 6 & 136 & 112 & 44 \\
Total & & & & & & & & & \\
\hline
\end{tabular}


According to Table 2, research population consists of 1431 students, 10 administrators and 136 teachers and 1577 people. $38.22 \%\left(n_{1}=133\right)$ of the participants were female, $65.52 \%\left(n_{1}=228\right)$ were students, $2.3 \%\left(n_{1}=\right.$ 8) were administrators, $32.18 \%\left(n_{1}=112\right)$ were teachers, $55.75 \%\left(n_{1}=194\right)$ were from Öztimurlar Vocational Technical High School and 44.15\% $\left(n_{1}=154\right)$ from Erkek High School. 59.5\% $\left(n_{2}=100\right)$ were male, $70.2 \%\left(n_{2}=\right.$ $118)$ were students, $3.6 \%\left(n_{2}=6\right)$ were administrators, $26.2 \%\left(n_{2}=44\right)$ were teachers, $36.9 \%\left(n_{2}=62\right)$ were from Öztimurlar Vocational Technical Anatolian High School and 63.1\% $(n=106)$ were from Erkek High School. Finally, in the first application 348, in the second application 168 people participated in the study.

\section{Academic Success Scale}

The scale consists of 26 items; 5 for school administrators and management style factor, 3 for teacherrelated factors, 4 for curriculum factor, 5 for teaching environment and contribution of parents factor, 5 for physical qualifications of school factor, 4 for the impact of students' individual characteristics. Scale consists of 6 dimensions. 5- Likert-Type rating was used as 5-It definitely affects the future expectations of students, 4-It affects students' academic success, 3-It partially affects the academic success of students, 2-It does not affect students' academic success, 1-It does not exactly affect the academic success of the students.

\section{Statistical Analysis}

After the application, data were processed and SPSS 23.0 and Lisrel Statistical Program were used for the analysis of the application. When the analyzes of the student, administrator and parent forms were made separately, since the sample number of the administrators and teachers was not sufficient for the analysis and the scale items in the forms were prepared in the same parallel as the content, the data of the student, teacher and administrator groups were combined into a single form and the application was repeated.

\section{RESULTS}

According to the results of the first application; before factor analysis, Kaiser Meyer Olkin (KMO) coefficient was calculated and Bartlett's Sphericity test was applied to determine the suitability of the data for factor analysis. KMO coefficient was calculated as .876 and Bartlett's Sphericity value $\left(\chi^{2}=1987.450, \mathrm{p}\right.$ $<.01)$ was determined. Accordingly, there is no relationship between the items, so factor analysis can be performed. Exploratory Factor Analysis the rotation analysis was performed with the "varimax method". As a result of the analysis, 6 dimensions were formed in the Academic Success Scale. We designed 7 dimensions in the preparation stage, because of the scale items were perceived in different dimensions by the participants we found 6 dimensions as a result of the first application. Teaching environment and contribution of parents dimensions perceived as one factor by participants. Student and physical qualifications of school dimensions were found to be significant and factor loadings were significant. Factor 
Erçetin,S.S., Güngör,H. \& Hamedoğlu,M.A. (2020). Academic success scale: Second-order confirmatory and exploratory factor analysis. International Journal of Educational Research Review,5(3),178-189.

loadings of 5 items in the size of administrator (1-2-3-4-5.), 1 item in the size of teacher (item 13), 3 items in the size of curriculum (items 18-19-20), 5 items in the dimension of teaching environment and contribution of parents $(6,8,7,21-22-23-24-25)$ were found to be low. Scale were prepared in three different forms for teachers, students and administrators in line with the answers given to open-ended questions asked to students, teachers and administrators during the application, and the scale was finalized as a single form and the application was repeated. The results of the second application are as follows.

\section{Table 3.}

Results of Factor Analysis for Second Application

\begin{tabular}{|c|c|c|c|c|c|c|}
\hline & Facto & & & & & \\
\hline & 1 & 2 & 3 & 4 & 5 & 6 \\
\hline A33 & .882 & & & & & \\
\hline A34 & .653 & & & & & \\
\hline A35 & .636 & & & & & \\
\hline A32 & .549 & & & & & \\
\hline A4 & & .834 & & & & \\
\hline A3 & & .747 & & & & \\
\hline A5 & & .680 & & & & \\
\hline A1 & & .671 & & & & \\
\hline A2 & & .664 & & & & \\
\hline A16 & & & .876 & & & \\
\hline A17 & & & .610 & & & \\
\hline A20 & & & .430 & & & \\
\hline A19 & & & .303 & & & \\
\hline A29 & & & & -.815 & & \\
\hline A28 & & & & -.740 & & \\
\hline A 27 & & & & -.683 & & \\
\hline A26 & & & & -.570 & & \\
\hline A30 & & & & -.536 & & \\
\hline A12 & & & & & -.629 & \\
\hline A14 & & & & & -.533 & \\
\hline A13 & & & & & -.495 & \\
\hline A6 & & & & & & .663 \\
\hline A8 & & & & & & .450 \\
\hline A21 & & & & & & .404 \\
\hline A25 & & & & & & .369 \\
\hline
\end{tabular}


Erçetin,S.S., Güngör,H. \& Hamedoğlu,M.A. (2020). Academic success scale: Second-order confirmatory and exploratory factor analysis. International Journal of Educational Research Review,5(3),178--189.

\begin{tabular}{lllllll}
\hline A22 & \multicolumn{7}{c}{} & & 301 \\
\hline $\begin{array}{l}\text { \% of } \\
\text { Variance }\end{array}$ & 29.914 & 10.706 & 4.834 & 3.444 & 3.294 & 3.109 \\
\hline $\begin{array}{l}\text { Cronbach's } \\
\text { Alpha }\end{array}$ & 0.883 & 0.838 & 0.797 & 0.877 & 0.894 & 0.715 \\
\hline $\begin{array}{l}\text { Cronbach's } \\
\text { Alpha }\end{array}$ & & & & & 0.894 \\
\hline
\end{tabular}

Factor analysis was performed by varimax method. As a result of factor analysis, it was observed that the items were grouped under six factors. The first factor variance of the scale was $29.914 \%$, the second factor variance was $10.706 \%$, the third factor variance was $4.834 \%$, the fourth factor variance was $3.444 \%$, the fifth factor variance was $3.294 \%$, and the sixth factor variance was $3.109 \%$.

When Table 3 is examined, factor loads of the first factor is ranging from .882 and .549; factor loads of the second factor is ranging from .834 and .664; factor loads of the third factor is ranging from .876 and .303; factor loads of fourth factor is ranging from .815 and .536 ; factor loads of the fifth factor is ranging from .629 to .495; factor loads of sixth factor is ranging between .663 and .301. The scale consists of 26 items. Factor analysis revealed that items $7,9,10,11,18,23,24$ were below the factor load of 300 .

The Cronbach alpha coefficient for the first factor was .883, for the second factor was .838 , for the third factor was .797, for the fourth factor was .877 , for the fifth factor was .894 , and the sixth factor was .894 . The Cronbach alpha coefficient of the scale was calculated as and the coefficient was .715. It can be said that the scale has high reliability and the items have discriminatory properties.

In the confirmatory factor analysis, the fit indices of the model (Erkorkmaz et al., 2013) were examined and Chi-square value $\left(X^{2}=574.04, \mathrm{sd}=290, \mathrm{p}=.000, X^{2} / \mathrm{sd}=1.979\right)$ was found to be significant. Compliance index values are given in Table 4.

Table 4.

Confirmatory Factor Analysis Fit Index Values

\begin{tabular}{|c|c|c|c|c|}
\hline Fit Measures & Good Fit & Acceptable Fit & $\begin{array}{l}\text { Measurement } \\
\text { Value }\end{array}$ & Fit \\
\hline$x^{2}$ & $0 \leq \chi 2 \leq 2 \mathrm{df}$ & $2 \mathrm{df} \leq \chi 2 \leq 3 \mathrm{df}$ & 574.04 & Good fit \\
\hline$p$ value & $0,05 \leq p \leq 1,00$ & $0,01 \leq p \leq 0,05$ & $\mathrm{P}<0.01$ & \\
\hline$\chi 2 / \mathrm{df}$ & $0 \leq \chi 2 / \mathrm{df} \leq 2$ & $2 \leq \chi 2 / \mathrm{df} \leq 3$ & 1.979 & Good fit \\
\hline RMSEA & $0<$ RMSEA $<0.05$ & $0,05 \leq \mathrm{RMSEA} \leq 0.10$ & 0.077 & Acceptable \\
\hline $\begin{array}{l}\text { P-Value for Test of } \\
\text { Close Fit }\end{array}$ & $0,10 \leq p \leq 1,00$ & $0,05 \leq p \leq 0,10$ & 0.000 & Poor fit \\
\hline SRMR & $0 \leq \mathrm{SRMR} \leq 0,05$ & $0,05<\mathrm{SRMR} \leq 0.10$ & 0.067 & Acceptable \\
\hline NFI & $0,95 \leq \mathrm{NFI} \leq 1$ & $0,90 \leq \mathrm{NFI} \leq 0,95$ & 0.88 & Poor fit \\
\hline
\end{tabular}


Erçetin,S.S., Güngör,H. \& Hamedoğlu,M.A. (2020). Academic success scale: Second-order confirmatory and exploratory factor analysis. International Journal of Educational Research Review,5(3),178--189.

\begin{tabular}{lllll}
\hline NNFI & $0,97 \leq$ NNFI $\leq 1$ & $0,95 \leq$ NNFI $\leq 0,97$ & 0.92 & Poor fit \\
CFI & $0,97 \leq \mathrm{CFI} \leq 1$ & $0,95 \leq \mathrm{CFI} \leq 0,97$ & 0.92 & Poor fit \\
GFI & $0,95 \leq \mathrm{GFI} \leq 1$ & $0,90 \leq \mathrm{GFI} \leq 0,95$ & 0.79 & Poor fit \\
AGFI & $0,90 \leq \mathrm{AGFI} \leq 1 \quad 0,85 \leq \mathrm{AGFI} \leq 0,90$ & 0.75 & Poor fit \\
AIC-Model & The comparison is smaller than the model's & $696.04<5592.10$ & Accept \\
& AIC & & Accept \\
CAIC-Model & The comparison is smaller than the model's & $947.61<5699.32$ & \\
& CAIC & & Accept \\
ECVI & The comparison is smaller than the model's & $4.17<33.49$ & \\
\hline
\end{tabular}

When Table 4 is examined, although the NFI value is lower than expected, this model was accepted because the chi square value was significant, the RMSEA, SRMR value showed acceptable agreement and the AIC Model, CAIC Model and ECVI value were acceptable. It is thought that the poor fit values obtained as a result of the analyzes may be caused by the fact that the sample taken in the study is small compared to the Bursa province, and the adaptation values will increase when the larger sample is studied. The construct validity of the scale was evaluated by second order confirmatory factor analysis using the highest likelihood method to evaluate the consistency between the obtained solution and the predicted model. The second order confirmatory factor analysis for the six-dimensional model is shown in Figure 1. 


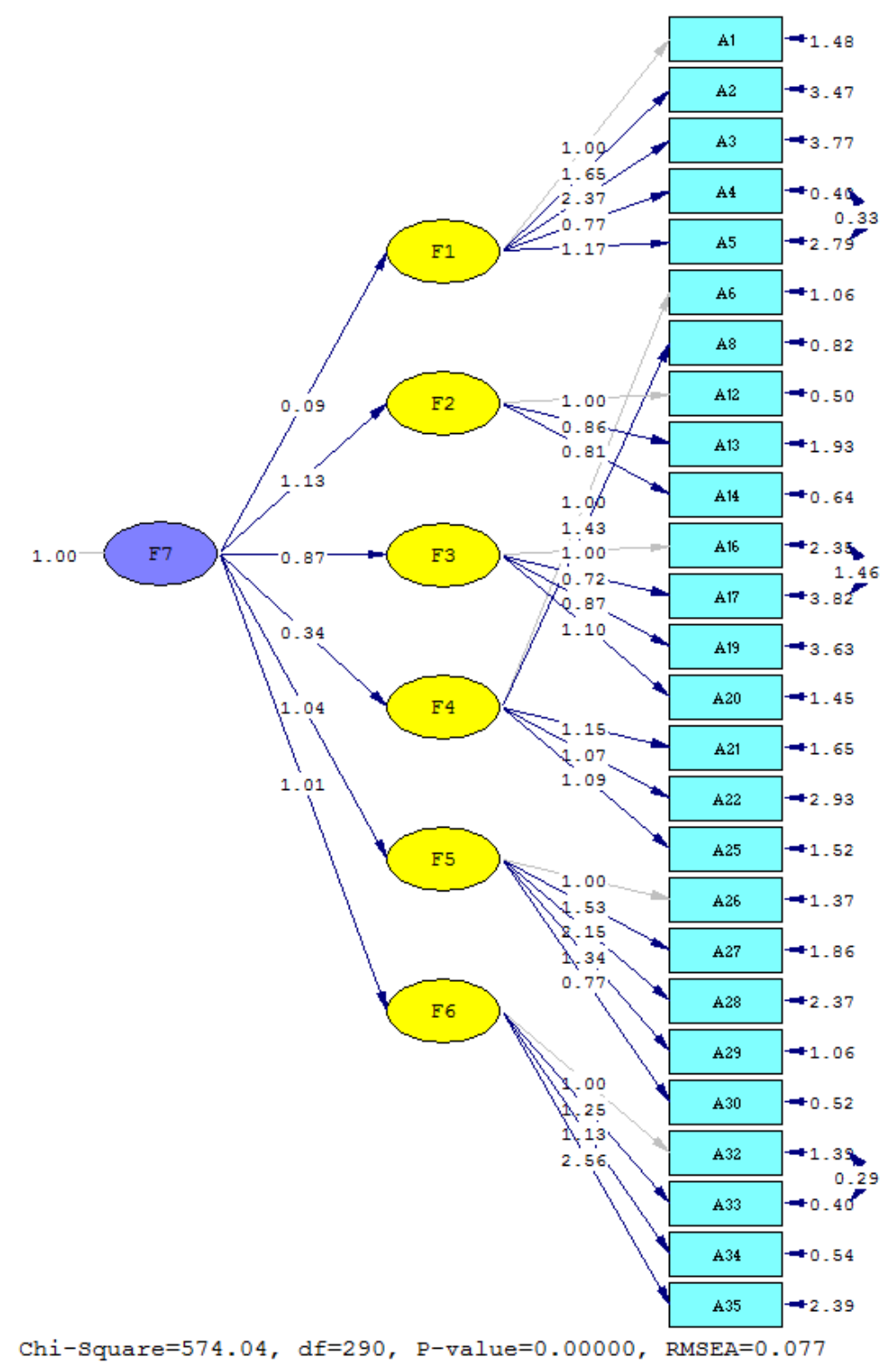

Figure 1. Second Order Confirmatory Factor Analysis

The 26-item 6-factor scale was found to be significant in the second order DFA adaptation index.

\section{DISCUSSION AND CONCLUSION}

Academic Success Scale was prepared in order to determine the factors affecting the academic success of students in the school environment during the preparation process for higher education. The model fit was tested with second order confirmatory factor analysis. Structural Equation Modeling was used to test the model. The aim of the second order factor analysis is to investigate how much the first order factors are loaded on the hypothesized second order factor, that is, to investigate how much school administrators and management style, teacher-related factors, curriculum, teaching environment and contribution of parents, physical qualifications of school, the impact of students' individual characteristics factors can predict academic success. As a result of exploratory and second order confirmatory factor analysis, the scale consisting of twenty six items and six factors was found to be theoretically and statistically appropriate.

Although we designed 7 dimensions in the preparation stage, because of the scale items were perceived in different dimensions by the participants we found 6 dimensions as a result of the first application. 
Teaching environment and contribution of parents dimensions perceived as one factor by participants. When we repeat the application, we found 6 dimensions again. This shows the consistency and reliability of the scale. The procedures performed during the development of the scale indicate that, it is a valid and reliable scale that measures the factors related to school that affect academic success. In addition, since there are a limited number of tools that measure school-related factors affecting academic success in the literature review, it is thought that the scale will contribute to the field and meet the need in this sense. Conducting researches in which the scale will be used in the literature sense will make significant contributions to the measurement power of this scale.

\section{REFERENCES}

Bakioğlu, A. \& Salduz, E. (2014). Öğretmenlerin hesap verebilirliklerini öğrencilerin akademik başarısı açısından değerlendirmeleri. Ĕ̆itim Bilimleri Dergisi, 40, 13-29.

Eker, C. \& Coşkun, İ. (2012). Ders günlüğü yazmanın ilkokul 4. sınıf öğrencilerinin sosyal bilgiler dersi akademik başarılarına etkisi. Muğla Sıtkı Koçman Üniversitesi Sosyal Bilimler Enstitüsü Dergisi, 2, 111-122.

Erçetin, Ş.Ş. \& Açıkalın, Ş.N. (2018). Understanding the New Generation Universities: Learning, Teaching and Managing. In Ş.Ş. Erçetin (Ed.) Chaos, Complexity and Leadership 2016. Springer Proceedings in

Complexity, Ch 16, pp. 209-215, Switzerland: Springer International Publishing, DOI https://doi.org/10.1007/978-3-319-64554-4 16

Erçetin, Ş.Ş. and Arifoğlu, A. (2016). Herkes için eğitim 2015 hedefleri ve Türkiye. Bartın Üniversitesi Eğitim Fakültesi Dergisi, 5(2), 223-246. Doi: http://dx.doi.org/10.14686/buefad.v5i2.5000186142

Erçetin, Ş.Ş. \& Bisaso S. M. (2018). The viability and reliability of the fractal leadership practices scale. In Ş.Ş. Erçetin (Ed.) Chaos, complexity and leadership 2016. Springer Proceedings in Complexity, Ch 8, pp.89-109, Switzerland: Springer International Publishing. DOI https://doi.org/10.1007/978-3-319-64554-4_8

Erçetin, Ş.Ş. \& Çevik, M.S. (2019). A study on validity and reliability of teacher efficacy scale. In Ş.Ş. Erçetin, N. Potas (Eds.) Chaos, complexity and leadership 2017: Explorations of chaos and complexity theory. Springer Proceedings in Complexity, Ch 38, pp 411-430, Cham, Springer International Publishing, DOI https://doi.org/10.1007/978-3-319-89875-9 34

Erkorkmaz, Ü., Etikan, İ., Demir, O., Özdamar, K. \& Sanisoğlu, S. Y. (2013). Doğrulayıcı faktör analizi ve uyum indeksleri. Türkiye Klinikleri, 33(1), 210-223.

Özer, H. \& Demir, A. (2008). Öğrenci Seçme Sınavi'na hazırlanan öğrencilerin başarılarını etkileyen faktörlerin belirlenmesi (Oltu Anadolu Lisesi öğrencileri için bir uygulama). Atatürk Üniversitesi Sosyal Bilimler Enstitüsü Dergisi, 11(1), 261-274. 


\section{THE SCALE OF ACADEMIC SUCCESS}

Items

\section{School Administrators and Management Style}

1 Explaining the rules to be followed by school administrators

2 Planning the studies that will support the success of the students in compensating the empty courses by the school administrators

3 School administrators guide students according to their interests, abilities and achievements in field / department choices

$4 \quad$ School administrators follow the student's absenteeism status

$5 \quad$ Organizing trial exams for students preparing for the exam by school administrators

\section{Teacher-Related Factors}

$6 \quad$ Teacher re-explaining when there is a subject that the student does not understand

$7 \quad$ Teachers benefit from technological tools such as smart board, projector, computer

8 Teacher to make the lesson enjoyable for the student while teaching

\section{Curriculum}

9 Consecutive courses such as mathematics and physics are challenged in the daily curriculum

10 Taking two exams on the same day

11 Short inhalation times

12 Making the textbooks used attractive for students

\section{Teaching Environment and Contribution of Parents}

13 Parents often come to school to meet the teacher

14 Parents support student participation in reinforcement courses at school

15 Focusing on club activities at school

16 Organization of university preparation courses at school

17 Increasing the number and diversity of places such as laboratory, music-painting workshop, sports hall in school environment

\section{Physical Qualifications of School}

18 Sufficient course materials in classrooms

19 Lack of warming problems at school

20 The school is clean

21 Airy classrooms

22 There is no sound during the course to prevent the flow of the course from outside

The Impact of Students' Individual Characteristics

23 Students do their homework regularly

24 Regular daily repetition of the student

25 Students know the methods of study

26 Pre-preparation of the student for exams 